\title{
REFORMULASI PERTANGGUNGJAWABAN PIDANA PADA PELAKU PROSTITUSI ONLINE: SUATU KAJIAN NORMATIF
}

\author{
Subaidah Ratna Juita, Ani Triwati, Agus Saiful Abib. \\ Dosen Fakultas Hukum Universitas Semarang \\ ABSTRAK
}

Salah satu usaha rasional yang digunakan untuk menanggulangi aktivitas prostitusi online adalah dengan pendekatan kebijakan hukum pidana melalui formulasi sanksi pidana sebagai wujud konkret pertanggungjawaban pidana pada pelaku prostitusi online. Belum adanya ketentuan yang mengatur mengenai pidana kepada para pengguna jasa prostitusi online menyebabkan tidak maksimalnya penanggulangan prostitusi online itu sendiri. Apabila tidak ada pengaturan nasional yang mengatur tentang hal tersbut, maka para pengguna jasa prostitusi online akan merasa aman dan tetap leluasa membeli jasa untuk kepuasan mereka semata, sementara hal tersebut bertentangan dengan berbagai aspek norma terutama norma hukum dalam masyarakat. Oleh karena itu diperlukan pembaharuan hukum pidana, terkait pertanggungjawaban pidana bagi para pengguna jasa prostitusi online. Metode penelitian yang digunakan adalah yuridis normatif, yaitu dengan mengkaji atau menganalisis data sekunder yang berupa bahan-bahan hukum primer, dengan memahami hukum sebagai perangkat peraturan atau normanorma positif di dalam sistem perundang-undangan yang mengatur mengenai prostitusi online, sekaligus juga menggunakan bahan hukum sekunder, dan tersier. Jadi penelitian ini dipahami sebagai penelitian kepustakaan (library research), yaitu penelitian terhadap data sekunder. Dengan demikian, pendekatan yuridis-normatif dalam penelitian digunakan untuk menganalisis permasalahan yang berkaitan dengan reformulasi kebijakan hukum pidana tentang pertanggungjawaban pidana pada pelaku prostitusi online.

\section{Kata kunci : Reformulasi Hukum Pidana, Pertanggungjawaban Pidana, Pelaku Prostitusi Online.}

\begin{abstract}
One rational business which was used for the review tackling online prostitution activities with approach is criminal law policy formulation through criminal sanctions as a concrete form of criminal liability prostitution on performers online. the absence of provisions to the criminal shown to the users of services online prostitution cause maximum reduction prostitution not that alone online. if no national regulatory about tersbut that set, then the users of services online will feel prostitution and remain safe buying free services to review their satisfaction semata, while the thing contrary aspect different norms, especially legal norms hearts society. therefore required by the renewal of criminal law, criminal liability subscribe for users of online prostitution services. the research method used is normative, ie reviewing with or analyzing secondary data the form of material-primary legal materials, by devices regulations to understand the law as a positive or norms hearts legislation system that set about prostitution online, using also simultaneously materials secondary law, and tertiary. so the singer research is understood as a point of departure library (library research), namely against secondary
\end{abstract}

Jurnal Dinamika Sosial Budaya, Volume 18, Nomor 1, Juni 2016 
data research. article search google thus, juridical-normative research approach used to review hearts analyze the problem relates with reformulating the criminal law criminal liabilityabout the prostitution performers online.

\section{Key word: Reformulation of Criminal Law, Criminal Liability, Actors Online Prostitution.}

\section{PENDAHULUAN}

Pemerintah memandang UndangUndang No. 11 Tahun 2008 tentang Informasi dan Transaksi Elektronik (ITE) mutlak diperlukan bagi Negara Indonesia, karena saat ini Indonesia merupakan salah satu Negara yang telah menggunakan dan memanfaatkan teknologi informasi secara luas dan efisien. Sehingga Pemerintah pada tanggal 26 April 2008 mensahkan berlakunya Undang-Undang tentang Informasi dan Transaksi Elektonik (ITE). Undang-Undang No. 11 Tahun 2008 tentang Informasi dan Transaksi Elektronik dimaksudkan dapat memberikan banyak manfaat, diantaranya untuk menjamin kepastian hukum bagi masyarakat yang melakukan transaksi elektronik, mendorong pertumbuhan ekonomi, mencegah terjadinya kejahatan berbasis teknologi informasi dan melindungi masyarakat pengguna jasa dengan memanfaatkan teknologi informasi. Hal ini sejalan dengan yang dikemukakan oleh Bambang Sunggono, yaitu hukum dalam perkembangannya tidak hanya dipergunakan untuk mengatur perilaku yang sudah ada dalam masyarakat dan mempertahankan pola-pola kebiasaan yang telah ada, melainkan lebih dari itu, hukum menjurus penggunaannya sebagai suatu sarana. Untuk melaksanakan tujuan-tujuan yang telah dipilih dan ditentukan sehingga dapat terwujud di dalam masyarakat diperlukan adanya beberapa sarana. Salah satu sarana yang cukup memadai adalah hukum dengan berbagai bentuk peraturan perundang-undangan yang ada. ${ }^{1}$

Bertolak dari uraian di atas maka upaya atau kebijakan untuk melakukan penanggulangan prostitusi online sebagai bagian dari tindak pidana di bidang teknologi informasi dapat dilakukan melalui pertanggungjawaban pidana pada pelaku prostitusi online dengan menggunakan sarana "penal" (hukum pidana) maka dibutuhkan kajian terhadap materi/substansi (legal subtance reform) prostitusi online saat ini khususnya yang terkait dengan pertanggungjawaban pidana pada pelaku.

Bertolak dari hal tersebut jelas cakupannya sangat luas, guna mencegah luasnya cakupan tersebut, dan untuk memudahkan pembahasan maka perlu dilakukan pembatasan permasalahan. Adapun permasalahan dalam penelitian ini adalah bagaimanakah reformulasi pertanggungjawaban pidana pada pelaku prostitusi online di masa yang akan datang?

Berdasarkan perumusan masalah di atas, penelitian ini bertujuan untuk mengetahui reformulasi pertanggungjawaban pidana pada pelaku prostitusi online di masa yang akan

\footnotetext{
1 Hukum adalah norma yang mengarahkan masyarakat untuk mencapai cita-cita serta keadaan tertentu dengan tidak mengabaikan dunia kenyataan. Oleh karena itu, hukum terutama dibuat dengan penuh kesadaran oleh negara dan digunakan untuk mencapai suatu tujuan tertentu. Bambang Sunggono, Hukum dan Kebijaksanaan Publik, (Jakarta: Sinar Grafika, tanpa tahun), halaman.76.
} 
datang berdasarkan perspektif kebijakan hukum pidana. Sementara itu Hasil penelitian ini diharapkan dapat memberikan kontribusi baik secara teoritis maupun secara praktis, yaitu:

1. Secara teoritis, hasil penelitian ini diharapkan dapat memberikan sumbangan pemikiran bagi ilmu pengetahuan, khususnya hukum pidana dalam kaitannya dengan pertanggungjawaban pidana pada pelaku prostitusi online dalam perspektif kebijakan hukum pidana.

2. Secara praktis, hasil penelitian diharapkan dapat memberikan manfaat bagi aparat penegak hukum untuk memperluas wacana mengenai penanggulangan prostitusi online khususnya yang berkaitan dengan pertanggungjawaban pidana pada pelaku prostitusi online. Bagi penentu kebijakan, penelitian ini diharapkan dapat memberikan masukan dalam menetapkan kebijakan mengenai perumusan dan penerapan pidana dalam rangka melengkapi dan penyempurnaan peraturan perundangan yang berkaitan dengan prostitusi online.

\section{KAJIAN PUSTAKA}

\section{a. Tinjauan tentang Kebijakan Hukum Pidana}

Hukum pidana sebagai suatu sistem hukum yang terdiri dari budaya (culture), struktur dan substansi hukum, sedangkan undang-undang merupakan bagian dari substansi hukum. Dengan demikian pembaharuan hukum pidana tidak sekedar memperbaharui perundang- undangan hukum pidana saja namun juga memperbaharui sektor-sektor lain seperti ilmu hukum pidana dan ide-ide hukum pidana melalui proses pendidikan dan pemikiran akademik. 2 Bahkan sebenarnya ruang lingkup kebijakan hukum pidana lebih luas daripada pembaharuan hukum pidana. Hal ini disebabkan karena kebijakan hukum pidana dilaksanakaan melalui tahaptahap konkretisasi/operasionalisasi/ fungsionalisasi hukum pidana yang terdiri dari :

1. Kebijakan formulatif/legislatif, yaitu tahap perumusan/penyusunan hukum pidana;

2. Kebijakan aplikatif/yudikatif, yaitu tahap penerapan hukum pidana;

3. Kebijakan administratif/eksekutif, yaitu tahap pelaksanaan hukum pidana. $^{3}$

Dalam hal ini pembaharuan hukum pidana lebih banyak berkaitan dengan tahap perumusan atau pembuatan hukum pidana atau berkaitan dengan kebijakan formulatif. Jelaslah bahwa kebijakan hukum pidana tidak dapat dipisahkan dari sistem hukum pidana. Dalam hal ini Marc Ancel menyatakan, bahwa setiap masyarakat yang terorganisir memiliki sistem hukum yang terdiri dari peraturan peraturan hukum pidana beserta sanksinya, suatu prosedur hukum pidana dan suatu mekanisme pelaksanaan pidana $^{4}$. Dalam hal ini A.Mulder mengemukakan, bahwa kebijakan hukum pidana ialah garis kebijakan untuk menentukan :

1. seberapa jauh ketentuanketentuan pidana yang berlaku perlu dirubah atau diperbaharui;

2. apa yang dapat diperbuat untuk mencegah terjadinya tindak pidana;

3. cara bagaimana penyidikan,

2 Barda Nawawi Arief, Beberapa Aspek Kebijakan Penegakan dan Pengembangan Hukum Pidana, Edisi Revisi, (Bandung : PT. Citra Aditya Bakti, 2005), halaman 11.

${ }^{3}$ Ibid., halaman 29.

${ }^{4}$ Ibid., halaman 28-29. 


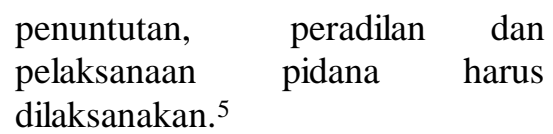

Dengan demikian kebijakan hukum pidana berkaitan dengan proses penegakan hukum (pidana) secara menyeluruh. Oleh sebab itu kebijakan hukum pidana diarahkan pada konkretisasi/operasionalisasi/

fungsionalisasi hukum pidana material (substansial), hukum pidana formal (hukum acara pidana), dan hukum pelaksanaan pidana.

Kebijakan menggunakan hukum pidana sebagai bagian dari politik kriminal pada dasarnya merupakan upaya yang rasional untuk menunjang dan mencapai "kesejahteraan sosial" (social welfare) dan "perlindungan sosial" (social defence). Dengan demikian, digunakannya hukum pidana sebagai salah satu sarana politik kriminal dan sarana politik sosial, dimaksudkan untuk melindungi kepentingan dan nilai-nilai sosial tertentu dalam rangka mencapai kesejahteraan sosial.

\section{b. Pertanggungjawaban Pidana}

$\begin{array}{cr}\text { Dalam } & \text { bahasa } \\ \text { pertanggungjawaban } & \text { pidana }\end{array}$
disebut sebagai, toerekenbaarheid, criminal responbility, liability. Pertanggungjawaban pidana dimaksudkan untuk menentukan apakah seseorang tersangka/terdakwa dipertanggungjawabkan atas suatu tindak pidana (crime) yang terjadi atau tidak. Dengan perkataan lain apakah terdakwa akan dipidana atau dibebaskan. Jika ia dipidana, harus ternyata bahwa tindakan yang dilakukan itu bersifat melawan hukum dan terdakwa mampu bertanggung jawab. Kemampuan tersebut memperlihatkan kesalahan dari petindak yang berbentuk kesengajaan atau kealpaan. Artinya tindakan tersebut tercela

$$
5 \text { Ibid. }
$$

tertuduh menyadari tindakan yang dilakukan tersebut. ${ }^{6}$

Pertanggungjawaban pidana adalah suatu perbuatan yang tercela oleh masyarakat yang harus dipertanggungjawabkan pada si pembuatnya atas perbuatan yang dilakukan. Dengan mempertanggung jawabkan perbuatan yang tercela itu pada si pembuatnya, apakah si pembuatnya juga dicela ataukah si pembuatnya tidak dicela. Pada hal yang pertama maka si pembuatnya tentu dipidana, sedangkan dalam hal yang kedua si pembuatnya tentu tidak dipidana. ${ }^{7}$ Dengan demikian kesalahan dalam arti seluas-luasnya, dapat disamakan dengan pengertian pertangungjawaban dalam hukum pidana. Didalamnya terkandung makna dapat dicelanya si pembuat atas perbuatannya. Jadi, apabila dikatakan bahwa orang itu bersalah melakukan sesuatu tindak pidana, maka itu berarti bahwa ia dapat dicela atas perbuatanya.

Menurut Roeslan Saleh :

Dalam pengertian perbuatan pidana tidak termasuk hal pertanggungjawaban. Perbuatan pidana hanya menunjuk kepada dilarangnya perbuatan. Apakah orang yang telah melakukan perbuatan itu kemudian juga dipidana, tergantung pada soal apakah dia dalam melakukan perbuatan itu memang mempunyai kesalahan atau tidak. Apabila orang yang melakukan perbuatan pidana itu memang mempunyai kesalahan,

6 E.Y.Kanter \& S.R Sianturi. Asasasas Hukum Pidana di Indonesia dan. Penerapannya. (Jakarta: Storia Grafika, 2002), halaman 249.

7 Roeslan Saleh, Pikiran-pikiran tentang Pertanggungjawaban Pidana, (Jakarta: Ghalia Indonesia, 1982), halaman 75-76. 
maka tentu dia akan dipidana. ${ }^{8}$

Pertanggungjawaban pidana menjurus kepada pemidanaan pelaku, jika telah melakukan suatu tindak pidana dan memenuhi unsur-unsurnya yang telah ditentukan dalam undangundang. Dilihat dari sudut terjadinya suatu tindakan yang terlarang (diharuskan), seseorang akan dipertanggungjawab-pidanakan atas tindakan-tindakan tersebut apabila tindakan tersebut bersifat melawan hukum (dan tidak ada peniadaan sifat melawan hukum atau rechtsvaardigingsgrond atau alasan pembenar) untuk itu. Dilihat dari sudut kemampuan bertanggungjawab, maka hanya seseorang yang yang "mampu bertanggung-jawab yang dapat dipertanggung-jawabkan. Dikatakan seseorang mampu bertanggung jawab (toerekeningsvatbaar), bilamana pada umumnya. ${ }^{9}$

Tegasnya bahwa, pertanggungjawaban pidana adalah merupakan pertanggungjawaban orang terhadap tindak pidana yang dilakukannya. Dengan demikian, terjadinya pertanggungawaban pidana karena telah ada tindak pidana yang dilakukan oleh seseorang. Dimana masyarakat telah sepakat menolak suatu perbuatan tertentu yang diwujudkan dalam bentuk larangan atas perbuatan tersebut. Sebagai konsekuensi penolakan masyarakat tersebut, sehingga orang yang melakukan perbuatan tersebut akan dicela, karena dalam kejadian tersebut sebenarnya pembuat dapat berbuat lain. Pertanggungjawaban pidana pada hakikatnya merupakan suatu mekanisme yang dibangun oleh hukum pidana untuk bereaksi terhadap pelanggaran atas kesepakatan menolak

${ }^{8}$ Ibid.

${ }^{9}$ E.Y.Kanter \& S.R Sianturi, $O p$. Cit., halaman. 249. suatu perbuatan tertentu.

\section{c. Landasan Pemahaman tentang Prostitusi Online}

Prostitusi online berasal dari dua kata yang masing-masing dapat berdiri sendiri yakni prostitusi dan online. Prostitusi berasal dari bahasa Belanda yaitu prostitutie, dan dalam bahasa Inggris yaitu prostitution yang artinya pelacuran. Prostitusi adalah istilah yang sama dengan pelacuran. Pelacuran menurut Soerjono Soekanto dapat diartikan sebagai suatu pekerjaan yang bersifat menyerahkan diri kepada umum untuk melakukan perbuatan-perbuatan seksual dengan mendapat upah. Pelacuran atau prostutisi adalah penyediaan layanan seksual yang dilakukan oleh laki-laki atau perempuan untuk mendapatkan uang atau kepuasan.

Dari beberapa perumusan tentang prostitusi sebagaimana dikemukakan oleh beberapa ahli di atas dapat ditarik suatu kesimpulan bahwa yang dimaksud dengan prostitusi adalah pekerja baik laki-laki maupun perempuan yang menyerahkan diri atau menjual jasa kepada khalayak umum untuk melakukan perbuatan-perbuatan seksual dengan mendapatkan upah sesuai dengan apa yang diperjanjikan sebelumnya.

Kata terakhir dari istilah prostitusi online menggambarkan tempat dimana aktivitas ini dilakukan. Online adalah istilah yang digunakan orang untuk menyatakan sesuatu yang berhubungan dengan internet atau dunia maya. Dengan demikian prostitusi online adalah kegiatan menawarkan jasa pelayanan seksual melalui dunia maya. Prostitusi online ini dapat didefenisikan secara garis besar adalah praktek prostitusi atau pelacuran dengan menggunakan media internet atau online sebagai sarana transaksi bagi mereka Perempuan Seks Komersil (PSK) dan yang ingin menggunakan jasanya. Walaupun jika ingin kita perdalam 
maknanya maka pengertian dari prostitusi online adalah transaksi pelacuran yang menggunakan media internet sebagai sarana penghubung antara PSK dengan yang ingin menggunakan jasanya. Jadi internet hanya sebagai sarana penunjang atau penghubung saja. Tidak seperti pada umumnya transaksi PSK yang menunggu pelanggannya dipinggirpinggir jalan. Semua definisi-definisi yang disebutkan memiliki masalahnya sendiri karena didefinisikan dari masyarakat yang berbeda yang pada dasarnya memiliki standar sosial dan moral yang berbeda-beda tentang prostitusi atau pelacuran itu.

Berdasarkan uraian di atas, maka prostitusi online merupakan transaksi prostitusi yang menggunakan media internet sebagai sarana penghubung antara pekerja seks komersial dengan yang ingin menggunakan jasanya. Jadi internet hanya sebagai sarana penunjang atau penghubung saja.

\section{METODE PENELITIAN}

\section{a. Metode Pendekatan}

Penelitian mengenai reformulasi pertanggungjawaban pidana pada pelaku prostitusi online ini merupakan penelitian hukum normatif, yaitu penelitian yang menitikberatkan pada data sekunder.

\section{b. Spesifikasi Penelitian}

Bertitik tolak dari judul dan permasalahan yang mendasari penelitian ini, maka penelitian ini termasuk jenis penelitian deskriptif- analitis, yaitu menggambarkan peraturan perundangundangan yang berlaku sebagai hukum positif dikaitkan dengan teori hukum dan praktek pelaksanaan hukum positif dalam masyarakat. Dengan demikian, dari penelitian ini dapat memberikan gambaran mengenai reorientasi kebijakan hukum pidana tentang pertanggungjawaban pidana pada pelaku prostitusi online.

\section{c. Jenis dan Sumber Data}

Sumber data yang digunakan dalam penelitian ini adalah data sekunder yang berupa bahan hukum primer, bahan hukum sekunder dan bahan hukum tersier, yaitu:

\section{- Bahan Hukum Primer}

Peraturan perundangundangan sebagai bahan hukum primer yang digunakan dalam penelitian ini adalah :

- Kitab Undang-Undang Hukum Pidana;

- Undang-Undang Nomor 23

Tahun 2002 tentang

Perlindungan Anak sebagaimana diubah dengan Undang-Undang Nomor 35 Tahun 2014 tentang Perubahan atas Undang-Undang Nomor 23 Tahun $2002 \quad$ Tentang Perlindungan Anak;

- Undang-Undang No. 44 Tahun 2008 tentang Pornografi;

- Undang-Undang No. 11 Tahun 2008 tentang Informasi dan Transaksi Elektronik.

\section{- Bahan Hukum Sekunder}

Bahan hukum sekunder adalah bahan hukum yang memberikan penjelasan mengenai bahan hukum primer, seperti hasil-hasil penelitian, yang diperoleh melalui bahan-bahan kepustakaan, berupa literatur-literatur seperti buku-buku teks (text books) yang ditulis para pakar hukum yang berpengaruh (de herseende leer), jurnal-jurnal hukum, pendapat para sarjana, kasus-kasus hukum, yurisprudensi. 10

\section{-Bahan Hukum Tersier}

10 Jhony Ibrahim, Teori dan Metodologi Penelitian Hukum Normatif, (Surabaya: Bayumedia, 2008), halaman 296. 
Bahan hukum tersier adalah bahan hukum yang memberikan petunjuk atau penjelasan terhadap bahan hukum primer dan bahan hukum sekunder ${ }^{11}$ berupa kamus umum, kamus bahasa, surat kabar, artikel, internet, dan ensiklopedi.

\section{d. Metode Pengumpulan Data}

Berdasarkan pendekatan yang dipergunakan dalam penelitian ini, maka metode pengumpulan data yang dipergunakan adalah studi kepustakaan atau dokumen (library research). Studi kepustakaan dilakukan terhadap data sekunder, yaitu data yang bersumber dari penelitian kepustakaan, dan diperoleh tidak secara langsung dari sumber pertamanya, melainkan bersumber dari data-data yang sudah terdokumentasi dalam bentuk bahanbahan hukum. Penelitian kepustakaan ini dimaksud untuk memperoleh data sekunder dengan mempelajari literaturliteratur, peraturan perundangundangan, teori-teori, pendapat para sarjana dan hal-hal lain yang berkaitan dengan kebijakan penal.

\section{e. Metode Analisis Data}

Analisis data dilakukan secara kualitatif kemudian diidentifikasi serta dilakukan kategorisasi. Analisis kualitatif yaitu metode analisis yang pada dasarnya menggunakan pemikiran logis, analisis dengan logika ${ }^{12}$. dengan induksi, deduksi, analogilinterpretasi, komparasi dan sejenis itu. ${ }^{13}$ Metode

\footnotetext{
11 Ibid.

${ }^{12}$ Analisis kualitatif pada dasarnya mempergunakan pemikiran logis analitis (lihat M. Sommers, Logika, (Bandung,: Alumni, 1992), halaman 2, demikian pula Jujun S. Suriasumantri, Filsafat IlmuSebuah Pengantar Populer, (Jakarta: Pustaka Sinar Harapan, 1996), halaman 43.

13 Tatang A. Amirin, Menyusun Rencana Penelitian, (Jakarta: CV. Rajawali, 1986 ), halaman 95. Menurut Niles dan Huberman, langkah-langkah ini untuk menganalisis data
}

berpikir yang digunakan adalah metode deduktif yaitu dengan berdasarkan pada dasar pengetahuan yang bersifat umum untuk mengkaji persoalan-persoalan yang bersifat khusus. Dari hasil analisis tersebut kemudian akan ditarik kesimpulan sebagai jawaban atas permasalahan yang ada.

\section{HASIL DAN PEMBAHASAN}

Masalah pertanggungjawaban pidana adalah merupakan segi lain dari subjek tindak pidana yang dapat dibedakan dari masalah si pembuat (yang melakukan tindak pidana). Artinya pengertian subyek tindak pidana dapat meliputi dua hal yaitu siapa yang melakukan tindak pidana (si pembuat) dan siapa yang dapat dipertanggungjawabkan.

Pada umumnya yang dapat dipertanggungjawabkan dalam hukum pidana adalah pembuat, tetapi tidaklah selalu demikian. Masalah ini tergantung juga pada cara atau sistem perumusan pertanggungjawaban yang ditempuh oleh pembuat undang-undang. Artinya penentuan masalah pertanggungjawaban pidana adalah siapa yang dapat dipertanggungjawabkan. Masalah ini menyangkut masalah subjek tindak pidana yang pada umumnya sudah dirumuskan oleh pembuat undangundang untuk tindakpidana yang bersangkutan. Menentukan subyek hukum yang dapat dimintai

meliputi pengumpulan data, reduksi data, display data dan formulasi kesimpulan. (Lihat Esmi Warassih, Metodologi Penelitian Bidang Ilmu Humaniora, Kompilasi makalah Pelatihan Metodologi Penelitian Ilmu Sosial, (Semarang: Bagian Hukum dan Masyarakat, Fakultas Hukum UNDIP 1999), halaman 51-52. Lihat pula: Matthrew B. Mikles \& A. Michael Huberman, Analisis Data Kualitatif, terj. Tjetjep Rehendy Rohidi, (Jakarta: UI Press, 1992), halaman 15-21. 
pertanggungjawaban pidana berarti harus didasari pada kebijakan formulasi suatu tindak pidana dan siapakah yang bertanggungjawab. Jika didasarkan pada hal tersebut, dalam menentukan dan merekonstruksikan subyek yang bertanggungjawab dalam hal terjadinya tindak pidana prostitusi online. Maka harus ditelaah dasar hukum atau sistem hukum yang menjadi pijakan untuk menentukannya.

Pertanggungjawaban pidana berdasarkan kesalahan terutama dibatasi pada perbuatan yang dilakukan dengan sengaja (dolus). Dapat dipidananya delik culpa hanya bersifat perkecualian (eksepsional) apabila ditentukan secara tegas oleh undangundang, sedangkan pertanggungjawaban terhadap akibatakibat tertentu dari suatu tindak pidana yang oleh undang-undang diperberat ancaman pidananya, hanya dikenakan kepada terdakwa apabila ia sepatutnya sudah dapat menduga kemungkinan terjadinya akibat itu atau apabila sekurang-kurangnya ada kealpaan. Jadi RKUHP tidak menganut doktrin menanggung akibat secara murni, tetapi tetap diorientasikan pada asas kesalahan. Hal ini terlihat dalam Pasal 40 RKUHP yang perumusannya adalah sebagai berikut:

(1) Seseorang hanya dapat dipertanggungjawabkan jika orang tersebut melakukan tindak pidana dengan sengaja atau karena kealpaan.

(2) Perbuatan yang dapat dipidana adalah perbuatan yang dilakukan dengan sengaja, kecuali peraturan perundang-undangan menentukan secara tegas bahwa suatu tindak pidana yang dilakukan dengan kealpaan dapat dipidana.

(3) Seseorang hanya dapat dipertanggungjawabkan terhadap akibat tindak pidana tertentu yang oleh Undang-Undang diperberat ancaman pidananya, jika ia mengetahui kemungkinan terjadinya akibat tersebut atau sekurang-kurangnya ada kealpaan.

Dalam hal ada kesesatan (error), baik error facti maupun error iuris, RKUHP berprinsip si pembuat tidak dapat dipertanggungjawabkan dan oleh karena itu tidak dapat dipidana. Namun demikian, apabila kesesatan itu (keyakinannya yang keliru itu) patut dicelakan atau dipersalahkan kepadanya, maka si pembuat tetapi dapat dipidana. Pendirian konsep KUHP yang demikian dirumuskan dalam Pasal 43 ayat (1) RKUHP yang berbunyi:

Tidak dipidana, jika seseorang tidak menge $\neg$ tahui atau sesat mengenai keadaan yang merupakan unsur tindak pidana atau berkeyakinan bahwa perbuatannya tidak merupakan suatu tindak pidana, kecuali ketidaktahuan, kesesatan, atau keyakinannya itu patut dipersalahkan kepadanya.

Secara normatif sudah menjadi kebiasaan setiap pembuat yang melakukan tindak pidana dan perbuatannya patut dipersalahkan dan bisa dibuktikan maka sudah sepatutnyalah si pembuat tersebut dihukum atau dikenakan pidana. Namun, RKUHP tidak menetapkan sesuai dengan hal konvensional di atas melainkan secara revolusioner memberikan kewenangan kepada hakim untuk mempertimbangkan untuk memberi maaf dan pengampunan. Maaf dan pengampunan di sini berarti si pembuat tidak dikenakan hukuman pidana atau tindakan apapun. Pedoman mengenai permaafan hakim ini dituangkan dalam Pasal 56 ayat (2) RKUHP sebagai bagian dari pedoman pemidanaan.

Dalam RKUHP 2015, pengaturan mengenai prostitusi dirumuskan dalam Pasal 470, yaitu: 


\begin{abstract}
Setiap orang yang memproduksi, membuat, memperbanyak, menggandakan, menyebarluaskan, menyiarkan, mengimpor, mengekspor, menawarkan, memperjualbelikan, menyewakan, atau menyediakan pornografi dipidana dengan pidana penjara paling lama 12 (dua belas) tahun atau pidana denda paling banyak Kategori V.
\end{abstract}

Delik prostitusi sebagaimana yang dirumuskan dalam Pasal 470 RKUHP ini dapat digunakan untuk menjangkau kegiatan prostitusi online, karena dalam rumusan tindak pidana dirumuskan bahwa materi-materi yang berkaitan dengan aktivitas prostitusi tersebut disiarkan atau disebarkan melalui media massa cetak, media massa elektronik dan/atau alat komunikasi media. Internet merupakan salah satu media massa elektronik, sehingga dapat dikategorikan sebagai media yang dapat digunakan untuk menyiarkan dan menyebarkan aktivitas prostitusi sebagaimana dirumuskan dalam delik. Selain itu, berkaitan dengan aspek jurisdiksi, RKUHP juga merumuskan jurisdiksi teritorial untuk mengantisipasi dan menjangkau kejahatan teknologi informasi, termasuk prostitusi yang diatur dalam Pasal 4 RKUHP yang menyatakan bahwa : Ketentuan pidana dalam peraturan perundang-undangan Indonesia berlaku bagi setiap orang yang melakukan:

1. tindak pidana di wilayah Negara Republik Indonesia;

2. tindak pidana dalam kapal atau pesawat udara Indonesia; atau

3. tindak pidana di bidang teknologi informasi yang akibatnya dirasakan atau terjadi di wilayah Indonesia atau dalam kapal atau pesawat udara Indonesia.

Prostitusi merupakan masalah yang tidak hanya melibatkan pelacurnya saja, tetapi lebih dari itu yaitu merupakan suatu kegiatan yang melibatkan banyak orang seperti germo, para calo, serta pengguna jasa yang sebagian besar pelakunya merupakan laki-laki yang sering luput dari perhatian aparat penegak hukum. Dalam ketentuan hukum positif yang ada di Indonesia hanya bisa mengenakan pertanggungjawaban pidana pada mereka yang membantu dan menyediakan pelayanan seks secara illegal, artinya pertanggungjawaban pidana hanya diberikan untuk mucikari atau germo, para calo, dan pelacur sedangkan pengguna jasa seks komersial sendiri sama sekali tidak ada pasal yang mengaturnya. Dalam pelaksanaannya, penanggulangan prostitusi lebih banyak dilakukan dengan menertibkan dan menangkap perempuan pelacur yang dilakukan oleh aparat penegak hukum, sedangkan lakilaki para pelanggan atau pengguna jasa seks komersialnya jarang dan bahkan tidak pernah ditangkap atau luput dari perhatian aparat penegak hukum. Cara penertiban seperti ini menunjukkan adanya ketidakadilan gender, karena terdapat diskriminasi terhadap perempuan. Adanya ketidakadilan gender dapat menyebabkan sulitnya penanggulangan prostitusi, karena pelacur merupakan paradigma interaksi antara perempuan dan laki-laki diluar perkawinan. Dalam interaksi tersebut perempuan diibaratkan sebagai pihak yang disewa, sedangkan laki-laki (pengguna jasa) sebagai pihak penyewa.

Penanggulangan prostitusi hanya pelacurnya saja selaku pihak yang disewa dikenakan sanksi pidana, sedangkan pihak yang menyewa tidak dapat diberi sanksi. Secara normatif diskriminasi terhadap perempuan telah dihapuskan berdasarkan Konvensi Wanita (CEDAW) yang telah diratifikasi dengan Undang-Undang Nomor 7 Tahun 1984. Namun dalam kenyataanya masih tampak adanya nilai- 
nilai budaya masyarakat yang bersifat diskriminatif. Hal tersebut dapat menghambat terwujudnya kesetaraan dan keadilan gender dalam penegakkan hukum terkait dengan penanggulangan prostitusi. Padahal jika merujuk pada hukum ekonomi, orang akan menyediakan jasa/barang dikarenakan adanya permintaan. Dengan demikian, pelacur muncul karena ada yg membutuhkan. Seharusnya jika ada istilah Wanita Tuna Susila (WTS) sebagai penjual layanan seks komersial harusnya juga ada istilah Pria Tuna Susila (PTS) sebagai pengguna jasa layanan seks komersial sebagai padanan yang tepat, sehingga dengan demikian baik laki-laki maupun perempuan yang terlibat dalam prostitusi mempunyai kedudukan yang sama untuk disalahkan, termasuk diberi label yang sama sebagai suatu perbuatan yang tidak bermoral.

Pengguna jasa merupakan gabungan dari dua kata yaitu pengguna dan jasa. Pengguna adalah orang yang menggunakan sesuatu 44, sedangkan jasa atau layanan adalah aktivitas ekonomi yang melibatkan sejumlah interaksi dengan konsumen atau dengan barang-barang milik, tetapi tidak menghasilkan transfer kepemilikan. ${ }^{14}$

Di Indonesia pemerintah tidak secara tegas melarang adanya praktekpraktek prostitusi. Dikatakan tidak tegas karena pengaturan mengenai tindak pidana prostitusi online tidak mengatur ketentuan mengenai sanksi pidana bagi pengguna jasa seks komersial, sehingga pengguna jasa prostitusi online tidak dapat dipertanggungjawabkan secara pidana, dan mereka yang menggunakan jasa pekerja seks komersialpun dapat dengan leluasa tanpa takut terjerat sanksi hukum pidana.

Melihat dari berbagai penjelasan pasal dalam KUHP, Undang-Undang Nomor 23 Tahun 2002 tentang Perlindungan Anak sebagaimana diubah dengan Undang-Undang Nomor 35 Tahun 2014 tentang Perubahan atas Undang-Undang Nomor 23 Tahun 2002 Tentang Perlindungan Anak, UndangUndang No. 44 Tahun 2008 tentang Pornografi, dan Undang-Undang No. 11 Tahun 2008 tentang Informasi dan Transaksi Elektronik belum berlaku efektif dalam menjerat dan menanggulangi bisnis prostitusi online, sama sekali tidak mengatur mengenai pengguna jasa dalam prostitusi online, sehingga pengguna jasa prostitusi itu sendiri tidak dapat dikenakan pertanggungjawaban secara pidana dan dijerat berdasarkan hukum positif yang ada di Indonesia. Seharusnya secara khusus dalam Undang-Undang No. 11 Tahun 2008 tentang Informasi dan Transaksi Elektronik dan UndangUndang No. 44 Tahun 2008 tentang Pornografi dapat menjerat subyek prostitusi itu secara keseluruhan.

Pengguna jasa prostitusi online pada dasarnya merupakan orang normal dan mampu bertanggungjawab. Pertanggungjawaban pidana terhadap pengguna jasa prostitusi dirasa perlu analisis yang mendalam dan hukum positif belum memadai untuk itu. Pembahasan mengenai aturan pidana telah memberi peringatan kepada para pembuat undang-undang terkait pengaturan yang belum ada dan dimungkinkan akan ada untuk kemudian berlaku nasional. Analisis pertanggungjawaban pidana dalam teori menjelaskan bahwa pertanggungjawaban pidana hanya dapat terjadi jika sebelumnya seseorang telah melakukan tindak pidana. Moeljatno mengatakan "orang tidak mungkin dipertanggungjawabkan (dijatuhi pidana) kalau dia tidak melakukan

${ }^{14}$ http://id.wikipedia.org/wiki/Jasa

diakses pada tanggal 14 Februari 2016. 
perbuatan pidana". 15 Artinya, pertanggungjawaban pidana hanya akan terjadi jika sebelumnya telah ada seseorang yang melakukan tindak pidana. Dalam konteks perundangan juga dikatakan bahwa ada tidaknya pidana ditentukan oleh peraturan perundang-undangan, yang diinterpretasikan bahwa tiada pertanggungjawaban pidana tanpa aturan hukum yang mengaturnya terlebih dahulu. ${ }^{16}$ Terhadap pengguna jasa prostitusi tidak dapat dipidana karena unsur-unsur tersebut di atas telah menjabarkan kelemahan hukum pidana dewasa ini. Kemudian dalam pemikiran hukum yang akan datang atau ius constituendum : hukum yang dicita-citakan oleh pergaulan hidup dan negara, tetapi belum menjadi kaidah berbentuk undang-undang atau peraturan lain, yaitu RKUHP belum mengatur perihal pidana terhadap mereka. Pada Bab XVI tentang Tindak Pidana Kesusilaan RKUHP tersebut belum mengaturnya. Pemikiran tentang perlunya aturan yang mengatur gejala sosial terhadap prostitusi khususnya bagi para pengguna jasanya ialah dasar yang kuat karena tindakan tersebut telah lumrah terjadi dan merupakan suatu fenomena keterpurukan bagi masyarakat banyak dan hukum khususnya pidana, diharapkan mengatur hal tersebut. Pihak pengguna inilah yang menjadi titik bagaimana bisa transaksi prostitusi online ini bisa terjadi. Walaupun tentu pihak lain itu juga memberikan dorongan hingga terjadinya praktek prostitusi ini. Namun pihak pengguna jasa inilah yang menjadi target bagi pemilik website atau forum prostitusi online untuk

${ }_{15}$ Moeljatno, Asas-asas Hukum Pidana, (Jakarta: Bina Aksara, 1987), halaman 155.

16 Chairul Huda, Dari Tiada Pidana Tanpa Kesalahan menuju kepada Tiada Pertanggungjawaban Pidana Tanpa Kesalahan, (Jakarta: Kencana Prenedia Media Group, 2011), halaman 20-21. menggunakan jasa PSK darinya.

\section{PENUTUP}

\section{a. Simpulan}

Reformulasi kebijakan hukum pidana tentang pertanggungjawaban pidana pada pelaku prostitusi online di masa yang akan datang (ius constituendum) dapat ditelusuri berdasarkan perumusan yang terdapat dalam Pasal 470 RKUHP. Perilaku buruk dalam masyarakat yaitu penggunaan jasa prostitusi yang terusmenerus secara signifikan bertumbuh dan berkembang akan mengakibatkan buruknya citra bangsa, demikian dengan para penegaknya yang terlihat tidak dapat berbuat apa-apa karena terhalang oleh belum adanya aturan yang mengatur mengenai pidana kepada para pengguna jasa prostitusi karena KUHP sampai saat ini belum mengatur secara tegas dan jelas mengenai pengguna jasa prostitusi. Apabila tidak ada pengaturan nasional yang mengatur maka para pengguna jasa prostitusi akan merasa aman dan tetap leluasa membeli jasa untuk kepuasan mereka semata, sementara hal tersebut bertentangan dengan berbagai aspek norma terutama norma hukum dalam masyarakat. Oleh karena itu diperlukan pembaharuan hukum pidana, terkait pertanggungjawaban pidana bagi para pengguna jasa prostitusi.

\section{b. Saran}

Perlu dilakukan pengkajian mendalam sehingga hukum pidana dapat menjangkau kejahatan prostitusi online yang dilaksanakan di dunia maya. Hal ini berarti diperlukan perluasan penafsiran sekaligus pembahasan mengenai perbandingan pertanggungjawaban pidana pada pelaku tindak pidana prostitusi online yang dapat menjangkau kegiatan di cyberspace dalam RKUHP yang akan 
menjadi ketentuan hukum positif.

\section{DAFTAR PUSTAKA}

a. Buku-buku:

Amirin, Tatang A. Menyusun Rencana Penelitian. Jakarta: CV. Rajawali, 1986.

Arief, Barda Nawawi. Bunga Rampai Kebijakan Hukum Pidana. Bandung: PT. Citra Aditya Bakti, 2002.

$\begin{array}{llr}\text { Kebijakan Penegakan dan } \\ \text { Pengembangan } & \text { Hukum } \\ \text { Pidana, Edisi } & \text { Revisi. } \\ \text { Bandung: PT. Citra } & \text { Aditya } \\ \text { Bakti, 2005. } & \end{array}$

----------------. Masalah Penegakan Hukum dan Kebijakan Penanggulangan Kejahatan. Cet ke-2. Bandung: PT. Citra Aditya Bakti, 2002.

Mayantara Perkembangan
Kajian Cyber Crime di
Indonesia.
RajaGrafindo Persada, 2006.

Asshidiqie, Jimli. Pembaruan Hukum Pidana Indonesia. Bandung : Angkasa, 1996.

Huda, Chairul. Dari Tiada Pidana Tanpa Kesalahan menuju kepada Tiada Pertanggungjawaban Pidana Tanpa Kesalahan. Jakarta: Kencana Prenedia Media Group, 2011.

Ibrahim, Jhony. Teori dan Metodologi Penelitian Hukum Normatif. Surabaya: Bayumedia, 2008.

Karnasudirja, Edy Junaedi. Jurisprudensi Kejahatan Komputer. Jakarta: Tanjung Agung, 1993.

Kanter, E.Y., dan S.R Sianturi. Asas-asas Hukum Pidana di
Indonesia dan Penerapannya. Jakarta: Storia Grafika, 2002.

Mikles, Matthrew B., dan A. Michael Huberman. Analisis Data Kualitatif. Terjemahan Tjetjep Rehendy Rohidi. Jakarta: UI Press, 1992.

Moeljatno. Asas-Asas Hukum Pidana. Jakarta: Bina Aksara, 1987.

Muladi. Demokratisasi, Hak Asasi Manusia dan Reformasi Hukum di Indonesia. Jakarta: The Habibie Center, 2002.

Mulia, T.S.G, et.al dalam Ensiklopedi Indonesia yang sebagaimana dikutip oleh Kartini Kartono, Patologi Sosial.

Roeslan, Saleh. Pikiran-pikiran tentang Pertanggungjawaban Pidana, (Jakarta: Ghalia Indonesia, 1982.

Sitompul, Asril. Hukum Internet: Pengenalan Mengenai Masalah Hukum di Cyberspace. Bandung : Citra Aditya Bakti, 2004.

Sunggono, Bambang. Metode Penelitian Hukum. Jakarta: PT. Raja Grafindo Persada, 2002.

Sutarman, Cyber Crime Modus Operandi dan Penanggulangannya.

Yogyakarta: LaksBang PRESSindo, 2007.

Wahid, Abdul dan Muhammad Labib. Kejahatan Mayantara (Cyber Crime. Bandung :Refika Aditama, 2005.

Wisnubroto, Aloysius. Kebijakan Hukum Pidana dalam Penanggulangan Penyalahgunaan Komputer. Yogyakarta: Universitas Atma Jaya, 1999. 
b. Peraturan Perundang-undangan:

Sekretariat Negara RI. UndangUndang No. 1 Tahun 1946 tentang Peraturan Hukum Pidana (KUHP). Jakarta, 1946.

Sekretariat Negara RI. UndangUndang Nomor 23 Tahun 2002 tentang Perlindungan Anak. Jakarta, 2002.

Sekretariat Negara RI. UndangUndang No. 11 Tahun 2008 tentang Informasi dan Transaksi Elektronik. Jakarta, 2008.

Sekretariat Negara RI. UndangUndang No. 44 Tahun 2008 tentang Pornografi. Jakarta, 2008.
Sekretariat Negara RI. UndangUndang Nomor 35 Tahun 2014 tentang Perubahan atas Undang-Undang Nomor 23 Tahun 2002 tentang Perlindungan Anak. Jakarta, 2014.

c. Website :

http://id.wikipedia.org

d. Lain-lain :

Rancangan Kitab UndangUndang Hukum Pidana (RKUHP) Tahun 2015 